\title{
academicjournals
}

Vol. 17(8), pp. 239-248, 21 February, 2018

DOI: 10.5897/AJB2017.16359

Article Number: 68CE78656049

ISSN 1684-5315

Copyright (C) 2018

African Journal of Biotechnology

Author(s) retain the copyright of this article

http://www.academicjournals.org/AJB

\section{Chlorella vulgaris DPSF 01: A unique tool for removal of toxic chemicals from tannery wastewater}

\author{
P. S. Subashini and P. Rajiv* \\ Department of Biotechnology, Karpagam Academy of Higher Education, Coimbatore, India.
}

Received 7 December, 2017; Accepted 25 January, 2018

\begin{abstract}
The present study investigated the removal of toxic pollutants and reduction of heavy metals from tannery wastewater using Chlorella vulgaris. The physiochemical parameters like $\mathrm{pH}$, electrical conductivity (EC), biological oxygen demand (BOD), chemical oxygen demand (COD), total solids (TS), total dissolved solids (TDS), chloride, total hardness (TH), bicarbonate, magnesium, ammoniacal nitrogen, phosphate and heavy metals $(\mathrm{Cu}, \mathrm{Cr}, \mathrm{Zn}, \mathrm{Ni}$ and $\mathrm{Fe}$ ) were analysed using standard methods. Functional group of toxic chemicals in tannery wastewater and $C$. vulgaris treated wastewater were analysed by Fourier transforms infrared spectroscopy (FT-IR) and gas chromatography - mass spectrometry (GC-MS). 20 to $60 \%$ of chemicals (bicarbonate, chloride, nitrogen, phosphate and magnesium) were reduced by the treatment using $C$. vulgaris within 28 days. FT-IR and GC-MS analysis reveals that the functional group of azo compounds was not in $C$. vulgaris treated wastewater. Thus, the results obtained conclude that $C$. vulgaris can be used as a suitable tool for the removal of toxic chemicals of tannery wastewater.
\end{abstract}

Key words: Chlorella vulgaris, toxic chemicals, tannery wastewater, physio-chemicals, Fourier Transforms Infrared Spectroscopy (FT-IR), Gas Chromatography - Mass Spectrometry (GC-MS).

\section{INTRODUCTION}

Nowadays, industries are releasing huge amount of wastewater without treatment and causing major water pollution and diseases. There are so many conventional methods such as chemical (chlorination) and physical (sedimentation process) available for wastewater treatments but having drawbacks (Suresh et al., 2015). India is ranked third in leather production in the world and $88 \%$ of tannery industries are in Tamilnadu, Uttar Pradesh and West Bengal. The maximum tannery industries are located near river basins in Tamilnadu. During leather production, there are various toxic chemicals that are used and wastewater is directly discharged into rivers without treatment. The largest organic and inorganic pollutants present in the urban and rural wastewater is due to industrial and anthropological activities (Bernhardt et al., 2008).

The biotechnological based treatments are useful for overcoming these problems. Bioremediation is a

*Corresponding author. E-mail: rajivsmart15@gmail.com. Tel/Fax: +9142226111146.

Author(s) agree that this article remains permanently open access under the terms of the Creative Commons Attribution License 4.0 International License 
worldwide acceptable technology in wastewater treatment. In bioremediation, bacteria, fungi and algae have been used. Algae are the best because it is less expensive and potential source of wastewater treatment compared to bacteria and fungi (Sheehan et al., 1998).

Microalgae are universally acknowledged in the purification of wastewater (Ayodhaya, 2013). Removal of organic and inorganic pollutants from wastewater by algae is known as phycoremediation. Phycoremediation is safe, efficient and eco-friendly for the removal of toxic materials including heavy metal from wastewater (Ding et al., 2014). The biomass of algae can be used for bio-fuel production after the wastewater treatment (Yadavalli et al., 2014). Various microalgae are used in the treatment of wastewater including Scenedesmus spp. (Ajayan and Selvaraju, 2012), Chlorella marina (Chellam and Sampathkumar, 2012), Chlorella vulgaris (Chu et al., 2008), Chlamydomonas and Digdigma proteus (Rehman et al., 2007), Oscillatoria, Ulotrix and Phormodium (Rai et al., 2005; Balaji et al., 2015).

This work aimed at evaluating the growth of $C$. vulgaris in tannery wastewater and its efficiency in reducing the pollution load of wastewater by examining the $\mathrm{pH}, \mathrm{EC}$, BOD, COD, TS, TDS, Chloride, TH, bicarbonate, magnesium, ammoniacal nitrogen, phosphate and heavy metals $(\mathrm{Cr}, \mathrm{Cu}, \mathrm{Fe}, \mathrm{Zn}$ and $\mathrm{Ni}$ ) of tannery wastewater before and after treatment.

\section{MATERIALS AND METHODS}

Collection of tannery wastewater and analysis of physiochemical parameters

Tannery wastewater was collected from the wastewater outlet of tannery industries located in the Erode (Latitude $-11.3410^{\circ} \mathrm{N}$, Longitude - $77.7172^{\circ}$ E) District, Tamilnadu, India. The collected samples were stored in sterile polythene bottles at $4^{\circ} \mathrm{C}$. The physiochemical parameters of tannery wastewater such as $\mathrm{pH}$, electrical conductivity, biological oxygen demand, chemical oxygen demand, total solids, total dissolved solids, chloride, total hardness, bicarbonate, magnesium, ammoniacal nitrogen and phosphate and heavy metals ( $\mathrm{Cr}, \mathrm{Cu}, \mathrm{Fe}, \mathrm{Zn}$ and $\mathrm{Ni}$ ) were assessed using standard methods (Clesceri et al., 1989).

\section{Collection of microalgae and chemicals}

C. vulgaris DPSF01 was collected from the Department of Marine Science, Bharathidasan University, Tiruchirappalli, Tamil nadu, India. It was grown in the Bold's Basal Medium (BBM) at 20 to $23^{\circ} \mathrm{C}$ under fluorescent lights (with $12 \mathrm{~h}$ light: $12 \mathrm{~h}$ dark photoperiods) (Nichols, 1973). The chemicals used for the preparation of media were purchased from MERCK, Mumbai, India.

\section{Phycoremediation}

The experimental designs were $T_{1} \quad(100 \%$ Raw tannery wastewater), $\mathrm{T}_{2}$ ( $75 \%$ of tannery wastewater diluted with tap water), $\mathrm{T}_{3}\left(60 \%\right.$ of tannery wastewater diluted with tap water), $\mathrm{T}_{4}(45 \%$ of tannery wastewater diluted with tap water), $\mathrm{T}_{5}(30 \%$ of tannery wastewater diluted with tap water) and $\mathrm{T}_{6} \quad(15 \%$ of tannery wastewater diluted with tap water) (Cindrella et al., 2016). The culture of $C$. vulgaris was centrifuged at $10,000 \mathrm{rpm}$ for $10 \mathrm{~min}$ and the supernatant was removed. The pellet of the algal cells were washed with sterile water and resuspended to inoculate into respective dilution. The density of $C$. vulgaris was about $30 \times 10^{3}$ cells $/ \mathrm{mL}$. The culture was grown for 28 days at a constant temperature of 15 to $20^{\circ} \mathrm{C}$ with the photoperiod of $12 \mathrm{~h}$ light and 12 $\mathrm{h}$ dark. At different time intervals $\left(7^{\text {th }}\right.$ day, $14^{\text {th }}$ day, $21^{\text {st }}$ day and $28^{\text {th }}$ day) the samples were collected and stored for further analysis (Ajayan and Selvaraju, 2011).

\section{Analysis of algal growth}

The algal growth was indirectly analysed by algal cell count method and estimated using hemocytometer during the treatment of tannery wastewater at different intervals $\left(7^{\text {th }}\right.$ day, $14^{\text {th }}$ day, $21^{\text {st }}$ day and $28^{\text {th }}$ day) according to Lenore (1998).

\section{Estimation of chlorophyll}

Chlorophyll ( $a$ and $b$ ) was estimated according to Arnon (1949). 20 $\mathrm{mL}$ of the culture was centrifuged at $10,000 \mathrm{rpm}$ for $10 \mathrm{~min}$. The collected pellet was mixed with $90 \%$ acetone. The mixture was centrifuged at $5000 \mathrm{rpm}$ for $10 \mathrm{~min}$; the absorbance value of supernatant was measured using UV-spectrometer (UV-2450, Shimadzu) at $663 \mathrm{~nm}$ (Chlorophyll a) and $645 \mathrm{~nm}$ (Chlorophyll b).

\section{Analysis of physio-chemical properties}

$20 \mathrm{~mL}$ of sample was taken and centrifuged at $10,000 \mathrm{rpm}$ for 20 $\mathrm{min}$; the pellet was discarded and the $\mathrm{pH}$ of supernatant analysed by $\mathrm{pH}$ meter (ELICO Model-107). The electrical conductivity of supernatant was assessed by digital EC meter (ELICO Model-180) (Lauber et al., 2009).

The assessment of $\mathrm{pH}, \mathrm{EC}, \mathrm{BOD}, \mathrm{COD}, \mathrm{TS}$, TDS, Chloride, Total Hardness, Bicarbonate, Magnesium, Ammoniacal nitrogen and Phosphate were followed by APHA (1989) method. The assessments were determined on seven days interval from $1^{\text {st }}$ day to $28^{\text {th }}$ day. Heavy metals $(\mathrm{Zn}, \mathrm{Cu}, \mathrm{Fe}, \mathrm{Ni}$ and $\mathrm{Cr}$ ) were assessed at different time intervals using Atomic Absorption Spectrophotometer (1983-400 HGA 900/AS 800 Perkin Elmer) and multi-Element Standard (MERCK-112837) (Fraile et al., 2005).

\section{Statistical analysis}

Experiments were carried out with three replications. Results are represented with means \pm standard errors for three independent experiments.

\section{FTIR and GC-MS analysis}

The functional groups of toxic chemicals from tannery wastewater before and after treatment were analysed by Fourier Transforms Infrared Spectroscopy (Perkin-Elmer 1725x). The treated and untreated wastewater were dissolved in methanol-water $(9: 1)(\mathrm{v} / \mathrm{v})$ and kept in a shaker overnight at room temperature. After the incubation period, the sample was filtered by using filter paper (Whatman No. 42, Maidstone, England). The filtrate was dried in 


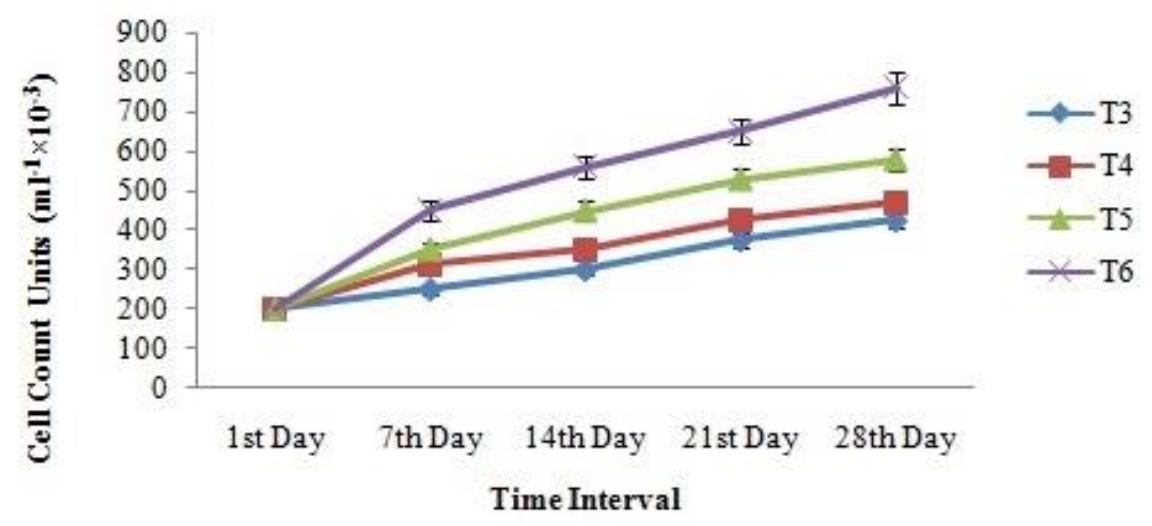

Figure 1. Cell count of Chlorella vulgaris on different concentration of tannery wastewater.
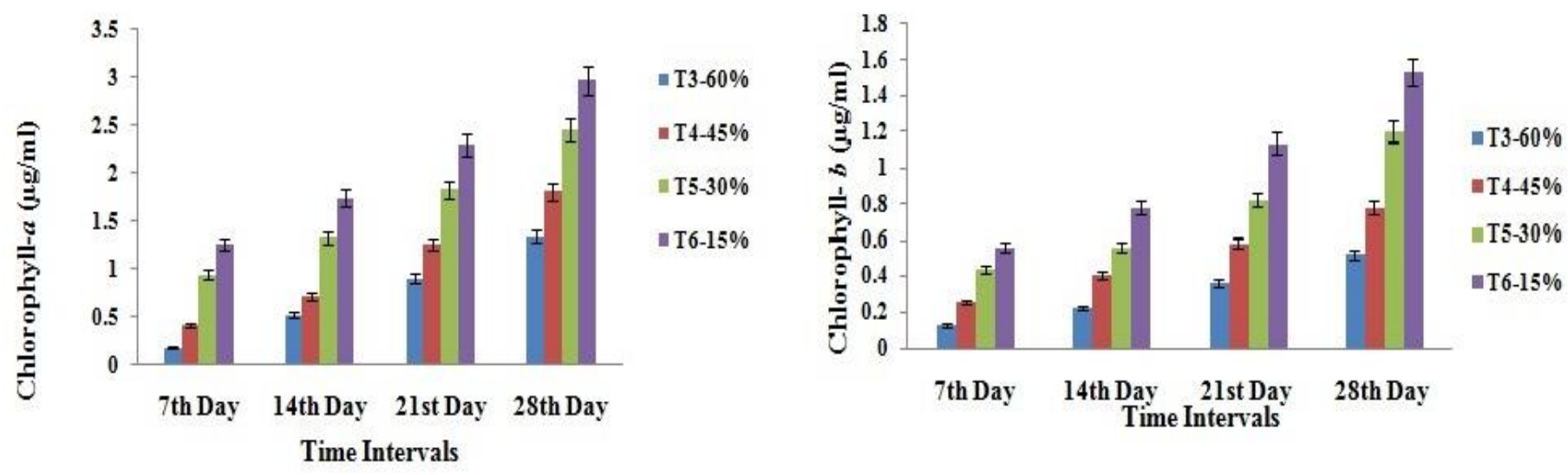

Figure 2. Analysis of chlorophyll- $a$ and $b$ of Chlorella vulgaris on different concentration of tannery wastewater.

hot air oven and the pellet was collected. The samples were analysed under the wavelength ranging between $400-4000 \mathrm{~cm}^{-1}$ (Kishore et al., 2015). Degradation of azo compounds was determined by GC-MS Thermo MS DSQ II, gas carrier helium (1.0 $\mathrm{mL} / \mathrm{min}$ ), capillary column (Ajay Kumar Pandey and Vinay Dubey, 2012).

\section{RESULTS AND DISCUSSION}

\section{Measuring the algal growth}

The maximum cell growth was found to be $760 \times 10^{3}$ cells $\mathrm{mL}^{-1}$ in $\mathrm{T}_{6}$ on the $28^{\text {th }}$ day whereas the lower growth was observed in $T_{3}$ and $T_{4}$ (Figure 1). The maximum growth of micro-algae in $T_{5}$ and $T_{6}$ treatment was due to heavy metal resistant mechanism and highest dilution of tannery wastewater (Rehman, 2011). The micro-algae were unable to grow in $T_{1}$ and $T_{2}$ treatments due to high amount of heavy metals and lower dilution of tannery wastewater (Ajayan et al., 2015).

\section{Estimation of chlorophyll}

The yield of chlorophyll ' $a$ ' and ' $b$ ' were high in $T_{5}$ and $T_{6}$ treatments on $28^{\text {th }}$ day (Figure $2 a$ and $b$ ). The Chlorophyll 'a' reached a maximum level of $2.97 \mu \mathrm{g} / \mathrm{mL}$ in $\mathrm{T}_{6}$ whereas $\mathrm{T}_{5}$ had $2.46 \mu \mathrm{g} / \mathrm{mL}$ on $28^{\text {th }}$ day. Chlorophyll $b$ was 1.54 and $1.20 \mu \mathrm{g} / \mathrm{mL}$ in $T_{6}$ and $T_{5}$, respectively. The present study proves that $C$. vulgaris was able to decolourise the tannery wastewater by dominant production of chlorophyll $a$ and $b$ (Hanumantha et al., 2011).

\section{Physio-chemical analysis of treated and untreated tannery wastewater}

Tables 1 and 2 present the physio-chemical parameters 
Table 1. Physio-chemical properties of tannery wastewater before and after treatment.

\begin{tabular}{clcc}
\hline $\mathbf{S} / \mathbf{N}$ & Parameters & Raw Effluent & Treated Effluent (15\% dilution) \\
\hline 1 & $\mathrm{pH}$ & $5.5 \pm 0.3$ & $7.78 \pm 0.20$ \\
2 & EC $(\mathrm{dsm}-1)$ & $13.01 \pm 0.4$ & $2.19 \pm 0.16$ \\
3 & Biological Oxygen Demand $\left(\mathrm{mg} \mathrm{L}^{-1}\right)$ & $1560 \pm 2.64$ & $333 \pm 4.58$ \\
4 & Chemical Oxygen Demand $\left(\mathrm{mg} \mathrm{L}^{-1}\right)$ & $2920 \pm 3.60$ & $1314 \pm 10.39$ \\
5 & Total Solids $\left(\mathrm{mg} \mathrm{L}^{-1}\right)$ & $7152 \pm 5.03$ & $2578 \pm 14.15$ \\
6 & Total Dissolved Solids $\left(\mathrm{mg} \mathrm{L}^{-1}\right)$ & $6370 \pm 2.88$ & $2348 \pm 7.83$ \\
7 & Chloride $\left(\mathrm{mg} \mathrm{L}^{-1}\right)$ & $590 \pm 5.23$ & $180 \pm 6.69$ \\
8 & Total hardness $\left(\mathrm{mg} \mathrm{L}^{-1}\right)$ & $1288 \pm 1.52$ & $428 \pm 8.25$ \\
9 & Bicarbonate $\left(\mathrm{mg} \mathrm{L}^{-1}\right)$ & $750 \pm 5.29$ & $177 \pm 7.26$ \\
10 & Magnesium $\left(\mathrm{mg} \mathrm{L}^{-1}\right)$ & $54 \pm 2.96$ & $26 \pm 4.35$ \\
11 & Ammoniacal Nitrogen $\left(\mathrm{mg} \mathrm{L}^{-1}\right)$ & $17 \pm 4.48$ & $8.12 \pm 0.60$ \\
12 & Phosphate $\left(\mathrm{mg} \mathrm{L}^{-1}\right)$ & $18 \pm 2.34$ & $10.68 \pm 1.63$ \\
\hline
\end{tabular}

of raw tannery wastewater and algal treated tannery wastewater respectively. The $\mathrm{pH}$ of the tannery wastewater increased from 5.5 to 7.78 in all the treatments $\left(T_{3}, T_{4}, T_{5}\right.$ and $\left.T_{6}\right)$. Due to the mechanism of photosynthesis, the microalgae reduced the concentration of dissolved $\mathrm{CO}_{2}$ hence the $\mathrm{pH}$ of tannery wastewater rose from acidic to alkaline on treatment (Borowitzka, 1998). The electrical conductivity of tannery wastewater reduced (from 11.51 to $2.19 \mathrm{dSm}^{-1}$ ) after the treatment. The reduction of BOD (1560 to $\left.333 \mathrm{mg} \mathrm{L}^{-1}\right)$ and COD (2920 to $1314 \mathrm{mg} \mathrm{L}^{-1}$ ) in C. vulgaris treated wastewater confirms the carbon dioxide sequestration. Balakumar et al. (2014) reported the carbon dioxide sequestration and reduction of green house gases from tannery wastewater using algal biomass. High amounts of xenobiotics compounds contribute in increasing the COD, which was reduced to about $90 \%$ by Chlorella (Sharma and Khan, 2013). The reduction of total solids (7152 to $2578 \mathrm{mg} \mathrm{L}^{-1}$ ) and total dissolved solids (6370 to $2348 \mathrm{mg} \mathrm{L}^{-1}$ ) during the treatment increases the cell count of $C$. vulgaris.

Algae are able to reduce TDS to base level by the mechanism of biosorption and adsorption (Nandha et al., 2010). The lowest total hardness was found in $T_{6}$ treatment $\left(428 \mathrm{mg} \mathrm{L}^{-1}\right)$ on the $28^{\text {th }}$ day while the 10 to $50 \%$ of total hardness were reduced by the treatment of C. vulgaris in tannery wastewater. Similar results were observed in lake and pond water treatment using Chlorococcum humicola (Sivasubramanian et al., 2012). The other chemical constituents (bicarbonate, chloride and magnesium) of tannery wastewater decreased from the $7^{\text {th }}$ to the $28^{\text {th }}$ day using the cultivation of $C$. vulgaris. The bicarbonate $\left(177 \mathrm{mg} \mathrm{L}^{-1}\right)$, chloride $\left(180 \mathrm{mg} \mathrm{L}^{-1}\right)$ and magnesium $\left(26 \mathrm{mg} \mathrm{L}^{-1}\right)$ were very low on $28^{\text {th }}$ day, because of the utilization of nutrients by $C$. vulgaris for their growth.

$50 \%$ of ammoniacal nitrogen was removed by the $C$. vulgaris which determines the denitrification and nitrification process by micro-algae (Durai and Rajasimman, 2011). Phosphate has been used for the production of ATP, phospholipids and nucleic acid hence phosphate was reduced (18 to $10.68 \mathrm{mg} \mathrm{L}^{-1}$ ) by the treatment of $C$. vulgaris in tannery wastewater (Becker, 1994).

\section{Efficiency of $C$. vulgaris on heavy metals removal}

Table 3 shows the reduction of heavy metals from tannery wastewater by $C$. vulgaris during the treatment process. Heavy metals $(71 \%$ of Copper, $50 \%$ of Zinc, $45 \%$ of Iron, $40 \%$ of Chromium and $20 \%$ of Nickel) were reduced by $C$. vulgaris. It shows that $C$. vulgaris is resistant to the toxicity of heavy metals in tannery wastewater. After 28 days, the reduction of heavy metals were in the following order; Copper > Zinc > Iron > Chromium > Nickel. Mehta and Gaur (2005) indicated the removal of heavy metals from wastewater by pretreatment of algae using $\mathrm{CaCl}_{2}$. The uptake of nickel by algae was stimulated by copper ions due to similar ionic properties and increased permeability of plasma membrane (Mehta et al., 2000). 50\% of zinc metal was removed by $C$. vulgaris in tannery wastewater. Similar results were reported by Dinesh Kumar et al. (2015). Chromium is predominantly present in tannery wastewater and $40 \%$ of chromium was removed by $C$. vulgaris. Hammouda et al. (2015) showed that $56.3 \%$ of chromium was removed by Chlorella when tannery wastewater was mixed with domestic wastewater.

\section{FTIR analysis of treated and untreated tannery wastewater}

FTIR spectrum of raw and treated tannery wastewater 
Table 2. Evaluation of physio-chemical parameters during phycoremediation of tannery wastewater.

\begin{tabular}{|c|c|c|c|c|c|}
\hline Treatments & $1^{\text {st }}$ day & $7^{\text {th }}$ day & $14^{\text {th }}$ day & $21^{\text {st }}$ day & $28^{\text {th }}$ day \\
\hline \multicolumn{6}{|c|}{ Physical parameter } \\
\hline \multicolumn{6}{|l|}{$\mathrm{pH}$} \\
\hline Control & $5.5 \pm 0.3$ & $5.5 \pm 0.1$ & $5.5 \pm 0.12$ & $5.5 \pm 0.8$ & $5.5 \pm 0.7$ \\
\hline $\mathrm{T}_{3}(60 \%)$ & $6 \pm 0.05$ & $6.15 \pm 0.08$ & $6.22 \pm 0.10$ & $6.28 \pm 0.12$ & $6.36 \pm 0.15$ \\
\hline $\mathrm{T}_{4}(45 \%)$ & $6.32 \pm 0.02$ & $6.40 \pm 0.08$ & $6.47 \pm 0.10$ & $6.55 \pm 0.12$ & $6.64 \pm 0.18$ \\
\hline $\mathrm{T}_{5}(30 \%)$ & $7 \pm 0.03$ & $7.17 \pm 0.05$ & $7.25 \pm 0.08$ & $7.27 \pm 0.10$ & $7.30 \pm 0.15$ \\
\hline $\mathrm{T}_{6}(15 \%)$ & $7.43 \pm 0.05$ & $7.48 \pm 0.10$ & $7.58 \pm 0.12$ & $7.65 \pm 0.15$ & $7.78 \pm 0.20$ \\
\hline \multicolumn{6}{|c|}{ Electrical conductivity $\left(\mathrm{dSm}^{-1}\right)$} \\
\hline Control & $13.01 \pm 0.4$ & $13.01 \pm 0.2$ & $13.01 \pm 0.4$ & $13.01 \pm 0.3$ & $13.01 \pm 0.6$ \\
\hline $\mathrm{T}_{3}(60 \%)$ & $11.51 \pm 0.10$ & $10.91 \pm 0.15$ & $10.11 \pm 0.12$ & $9.89 \pm 0.08$ & $9.55 \pm 0.15$ \\
\hline $\mathrm{T}_{4}(45 \%)$ & $9.49 \pm 0.09$ & $8.78 \pm 0.13$ & $8.22 \pm 0.09$ & $7.47 \pm 0.10$ & $6.71 \pm 0.11$ \\
\hline $\mathrm{T}_{5}(30 \%)$ & $7.46 \pm 0.07$ & $6.84 \pm 0.14$ & $6.27 \pm 0.08$ & $5.45 \pm 0.14$ & $4.57 \pm 0.16$ \\
\hline $\mathrm{T}_{6}(15 \%)$ & $5.33 \pm 0.15$ & $4.65 \pm 0.13$ & $3.92 \pm 0.15$ & $3.05 \pm 0.14$ & $2.19 \pm 0.16$ \\
\hline \multicolumn{6}{|c|}{ Chemical parameter } \\
\hline \multicolumn{6}{|c|}{ Biological oxygen demand $\left(\mathrm{mg} \mathrm{L}^{-1}\right)$} \\
\hline Control & $1560 \pm 2.64$ & $1560 \pm 2.88$ & $1560 \pm 1.15$ & $1560 \pm 1.73$ & $1560 \pm 2.64$ \\
\hline $\mathrm{T}_{3}(60 \%)$ & $1535 \pm 2.88$ & $1473 \pm 2.51$ & $1405 \pm 6.65$ & $1336 \pm 7.93$ & $1266 \pm 7.57$ \\
\hline $\mathrm{T}_{4}(45 \%)$ & $1467 \pm 7.23$ & $1335 \pm 6.35$ & $1210 \pm 11.26$ & $1080 \pm 10$ & $954 \pm 11.37$ \\
\hline $\mathrm{T}_{5}(30 \%)$ & $1379 \pm 8.14$ & $1194 \pm 12.49$ & $1014 \pm 3.21$ & $836 \pm 5.29$ & $647 \pm 8.14$ \\
\hline $\mathrm{T}_{6}(15 \%)$ & $1251 \pm 11.15$ & $1015 \pm 8.73$ & $787 \pm 11.93$ & $562 \pm 15.39$ & $333 \pm 4.58$ \\
\hline \multicolumn{6}{|c|}{ Chemical oxygen demand $\left(\mathrm{mg} \mathrm{L}^{-1}\right)$} \\
\hline Control & $2920 \pm 3.60$ & $2920 \pm 4.04$ & $2920 \pm 4.72$ & $2920 \pm 2.00$ & $2920 \pm 6.88$ \\
\hline $\mathrm{T}_{3}(60 \%)$ & $2887 \pm 8.11$ & $2815 \pm 10.11$ & $2744 \pm 6.08$ & $2671 \pm 10.14$ & $2602 \pm 13.89$ \\
\hline $\mathrm{T}_{4}(45 \%)$ & $2822 \pm 8.08$ & $2685 \pm 13.69$ & $2543 \pm 8.14$ & $2407 \pm 5.81$ & $2265 \pm 6.24$ \\
\hline $\mathrm{T}_{5}(30 \%)$ & $2705 \pm 8.73$ & $2507 \pm 10.58$ & $2301 \pm 10.97$ & $2075 \pm 13.22$ & $1839 \pm 9.13$ \\
\hline $\mathrm{T}_{6}(15 \%)$ & $2527 \pm 9.52$ & $2235 \pm 7.37$ & $1922 \pm 8.62$ & $1617 \pm 10.92$ & $1314 \pm 10.39$ \\
\hline \multicolumn{6}{|c|}{ Total solids $\left(\mathrm{mg} \mathrm{L}^{-1}\right)$} \\
\hline Control & $7152 \pm 5.03$ & $7152 \pm 5.50$ & $7152 \pm 3$ & $7152 \pm 3.84$ & $7152 \pm 5.78$ \\
\hline $\mathrm{T}_{3}(60 \%)$ & $6814 \pm 8.83$ & $6356 \pm 11.05$ & $5846 \pm 7.05$ & $5328 \pm 6.38$ & $4746 \pm 4.33$ \\
\hline $\mathrm{T}_{4}(45 \%)$ & $6410 \pm 8.95$ & $5858 \pm 4.09$ & $5290 \pm 6.42$ & $4737 \pm 9.24$ & $4152 \pm 7.02$ \\
\hline $\mathrm{T}_{5}(30 \%)$ & $5937 \pm 5.85$ & $5304 \pm 11.56$ & $4662 \pm 6.69$ & $3995 \pm 4.91$ & $3345 \pm 12.53$ \\
\hline $\mathrm{T}_{6}(15 \%)$ & $5399 \pm 5.20$ & $4673 \pm 11.93$ & $3967 \pm 11.66$ & $3266 \pm 7.93$ & $2578 \pm 14.15$ \\
\hline \multicolumn{6}{|c|}{ Total dissolved solids (mg L ${ }^{-1}$ ) } \\
\hline Control & $6370 \pm 2.88$ & $6370 \pm 3.38$ & $6370 \pm 4.37$ & $6370 \pm 3.51$ & $6370 \pm 5.29$ \\
\hline $\mathrm{T}_{3}(60 \%)$ & $6058 \pm 3.71$ & $5530 \pm 2.51$ & $5047 \pm 3.75$ & $4527 \pm 2.40$ & $4014 \pm 7.12$ \\
\hline $\mathrm{T}_{4}(45 \%)$ & $5636 \pm 5.85$ & $5145 \pm 7.68$ & $4647 \pm 5.60$ & $4141 \pm 6.65$ & $3605 \pm 5.45$ \\
\hline $\mathrm{T}_{5}(30 \%)$ & $5068 \pm 4.97$ & $4553 \pm 5.60$ & $4067 \pm 6.00$ & $3591 \pm 4.93$ & $3104 \pm 7.21$ \\
\hline $\mathrm{T}_{6}(15 \%)$ & $4399 \pm 7.05$ & $3893 \pm 10.36$ & $3411 \pm 6.65$ & $2887 \pm 7.81$ & $2348 \pm 7.83$ \\
\hline \multicolumn{6}{|c|}{ Total hardness $\left(\mathrm{mg} \mathrm{L}^{-1}\right)$} \\
\hline Control & $1288 \pm 1.52$ & $1288 \pm 5.36$ & $1288 \pm 3.60$ & $1288 \pm 4.91$ & $1288 \pm 5.81$ \\
\hline $\mathrm{T}_{3}(60 \%)$ & $1265 \pm 4.84$ & $1224 \pm 4.16$ & $1186 \pm 4.33$ & $1146 \pm 7.05$ & $1106 \pm 3.92$ \\
\hline $\mathrm{T}_{4}(45 \%)$ & $1179 \pm 4.58$ & $1106 \pm 6.43$ & $1037 \pm 6.17$ & $969 \pm 5.81$ & $900 \pm 4.61$ \\
\hline $\mathrm{T}_{5}(30 \%)$ & $1050 \pm 5.77$ & $958 \pm 7.05$ & $866 \pm 8.08$ & $774 \pm 4.35$ & $675 \pm 6.11$ \\
\hline $\mathrm{T}_{6}(15 \%)$ & $887 \pm 6.33$ & $772 \pm 6.35$ & $662 \pm 4.16$ & $550 \pm 7.50$ & $428 \pm 8.25$ \\
\hline
\end{tabular}


Table 2. Contd.

\begin{tabular}{|c|c|c|c|c|c|}
\hline \multicolumn{6}{|l|}{ Chloride $\left(\mathrm{mg} \mathrm{L}^{-1}\right)$} \\
\hline Control & $590 \pm 5.23$ & $590 \pm 4.93$ & $590 \pm 5.68$ & $590 \pm 6.42$ & $590 \pm 4.72$ \\
\hline $\mathrm{T}_{3}(60 \%)$ & $578 \pm 8.71$ & $566 \pm 8.71$ & $551 \pm 5.56$ & $538 \pm 2.51$ & $524 \pm 7.37$ \\
\hline $\mathrm{T}_{4}(45 \%)$ & $560 \pm 5.13$ & $527 \pm 5.48$ & $492 \pm 7.21$ & $461 \pm 6.08$ & $425 \pm 5.29$ \\
\hline $\mathrm{T}_{5}(30 \%)$ & $535 \pm 4.58$ & $476 \pm 4.91$ & $426 \pm 7.75$ & $368 \pm 5.77$ & $311 \pm 8.38$ \\
\hline $\mathrm{T}_{6}(15 \%)$ & $477 \pm 7.68$ & $401 \pm 5.20$ & $330 \pm 6.08$ & $252 \pm 5.68$ & $180 \pm 6.69$ \\
\hline \multicolumn{6}{|c|}{ Bicarbonate $\left(\mathrm{mg} \mathrm{L}^{-1}\right)$} \\
\hline Control & $750 \pm 5.29$ & $750 \pm 3.05$ & $750 \pm 4.50$ & $750 \pm 5.56$ & $750 \pm 2.64$ \\
\hline $\mathrm{T}_{3}(60 \%)$ & $735 \pm 5.50$ & $715 \pm 7.68$ & $687 \pm 7.57$ & $661 \pm 6.65$ & $634 \pm 4.40$ \\
\hline $\mathrm{T}_{4}(45 \%)$ & $708 \pm 4.16$ & $657 \pm 5.92$ & $602 \pm 5.48$ & $549 \pm 6.35$ & $497 \pm 5.54$ \\
\hline $\mathrm{T}_{5}(30 \%)$ & $643 \pm 6.35$ & $568 \pm 5.36$ & $495 \pm 4.09$ & $423 \pm 5.68$ & $348 \pm 8.08$ \\
\hline $\mathrm{T}_{6}(15 \%)$ & $571 \pm 6.35$ & $473 \pm 4.63$ & $373 \pm 3.92$ & $272 \pm 5.89$ & $177 \pm 7.26$ \\
\hline \multicolumn{6}{|c|}{ Magnesium $\left(\mathrm{mg} \mathrm{L}^{-1}\right)$} \\
\hline Control & $54 \pm 2.96$ & $54 \pm 4.40$ & $54 \pm 3.78$ & $54 \pm 4.66$ & $54 \pm 2.64$ \\
\hline $\mathrm{T}_{3}(60 \%)$ & $53 \pm 4.93$ & $51 \pm 4.35$ & $48 \pm 2.60$ & $44 \pm 4.05$ & $41 \pm 3.78$ \\
\hline $\mathrm{T}_{4}(45 \%)$ & $51 \pm 4.35$ & $47 \pm 2.64$ & $42 \pm 4.05$ & $39 \pm 5.23$ & $33 \pm 4.16$ \\
\hline $\mathrm{T}_{5}(30 \%)$ & $49 \pm 2.60$ & $43 \pm 3.48$ & $36 \pm 3.60$ & $31 \pm 4.04$ & $24 \pm 4.16$ \\
\hline $\mathrm{T}_{6}(15 \%)$ & $45 \pm 4.72$ & $41 \pm 3.78$ & $37 \pm 3.78$ & $32 \pm 3.48$ & $26 \pm 4.35$ \\
\hline \multicolumn{6}{|c|}{ Ammoniacal Nitrogen $\left(\mathrm{mg} \mathrm{L}^{-1}\right)$} \\
\hline Control & $17 \pm 4.48$ & $17 \pm 4.72$ & $17 \pm 3.21$ & $17 \pm 2.64$ & $17 \pm 4.72$ \\
\hline $\mathrm{T}_{3}(60 \%)$ & $16.5 \pm 3.06$ & $15.62 \pm 2.98$ & $14.39 \pm 2.34$ & $12.5 \pm 2.01$ & $10.48 \pm 0.36$ \\
\hline $\mathrm{T}_{4}(45 \%)$ & $16.15 \pm 3.09$ & $15.22 \pm 2.72$ & $14.1 \pm 2.57$ & $12.51 \pm 2.95$ & $10.29 \pm 1.66$ \\
\hline $\mathrm{T}_{5}(30 \%)$ & $16.02 \pm 2.59$ & $14.33 \pm 2.04$ & $12.78 \pm 1.95$ & $11.03 \pm 1.31$ & $9.37 \pm 1.76$ \\
\hline $\mathrm{T}_{6}(15 \%)$ & $15.97 \pm 1.76$ & $13.99 \pm 1.82$ & $11.97 \pm 1.14$ & $10.08 \pm 1.51$ & $8.12 \pm 0.60$ \\
\hline \multicolumn{6}{|c|}{ Phosphate $\left(\mathrm{mg} \mathrm{L}^{-1}\right)$} \\
\hline Control & $18 \pm 2.34$ & $18 \pm 2.15$ & $18 \pm 1.62$ & $18 \pm 2.05$ & $18 \pm 1.66$ \\
\hline $\mathrm{T}_{3}(60 \%)$ & $17.80 \pm 1.56$ & $17.55 \pm 0.86$ & $17.02 \pm 1.92$ & $16.92 \pm 1.17$ & $16.51 \pm 3.28$ \\
\hline $\mathrm{T}_{4}(45 \%)$ & $17 \pm 4.72$ & $16.56 \pm 3.30$ & $15.96 \pm 3.04$ & $15.12 \pm 2.67$ & $14.62 \pm 2.53$ \\
\hline $\mathrm{T}_{5}(30 \%)$ & $16.01 \pm 3.11$ & $15.18 \pm 2.71$ & $14.26 \pm 2.61$ & $13.29 \pm 1.70$ & $12.67 \pm 3.11$ \\
\hline $\mathrm{T}_{6}(15 \%)$ & $14.98 \pm 2.56$ & $13.91 \pm 1.72$ & $12.86 \pm 3.19$ & $11.98 \pm 2.15$ & $10.68 \pm 1.63$ \\
\hline
\end{tabular}

are shown in Figure $3 a$ and b. A peak at $3510 \mathrm{~cm}^{-1}$ represents $\mathrm{NH}_{2}$ group of aromatic amines. The region between $3420-3250 \mathrm{~cm}^{-1}$ indicates the presence of $\mathrm{OH}$ group of alcohols and phenols. A broad peak at $2250 \mathrm{~cm}$ ${ }^{1}$ indicates $\mathrm{C} \equiv \mathrm{C}$ of alkynes. The FTIR data of raw tannery wastewater (Figure 3a) shows the presence of azo group from the region between 1539 to $1580 \mathrm{~cm}^{-1}$. The wave number $1315 \mathrm{~cm}^{-1}$ shows the presence of $\mathrm{SO}_{2}$ in sulfones (Figure 3a).

The peak value between 3200 to $3600 \mathrm{~cm}^{-1}$ represents the stretching vibration of $\mathrm{O}-\mathrm{H}$ and $\mathrm{N}-\mathrm{H}$ group; the peak value $1258 \mathrm{~cm}^{-1}$ indicates the stretching of phosphodiester $(>\mathrm{P}=\mathrm{O})$ in nucleic acid of microalgae (Dilek et al., 2012); whereas the peak value of $2756 \mathrm{~cm}^{-1}$ indicates the stretching of $\mathrm{OH}$ group of carboxylic acid on treated water. A net negative charge formed by the carboxyl, hydroxyl, amino and sulphydryl groups on the cell surface confirms the high affinity for the binding of heavy metals (Deng et al., 2007; Gupta and Rastogi, 2008). The region between 1080 to $1040 \mathrm{~cm}^{-1}$ denotes the presence of $\mathrm{SO}_{3} \mathrm{H}$ in sulfonic acid. Gardea-Torresdey et al. (1990) reported that the carboxyl group has a higher metal binding capacity followed by $-\mathrm{OH},-\mathrm{SO}_{3} \mathrm{H}$ and $-\mathrm{P}_{2} \mathrm{O}_{3}$.

In Figure $3 \mathrm{~b}$ (treated tannery wastewater), there was no peak value between 1539- $1580 \mathrm{~cm}^{-1}$ indicating the absence of azo group. The comparative FTIR spectra analysis of treated and untreated tannery wastewater reveals that the absorption peak of azo compound groups was not present in the treated wastewater. 
Table 3. Heavy metals analysis of raw and treated tannery wastewater.

\begin{tabular}{|c|c|c|c|c|}
\hline Treatments & $7^{\text {th }}$ Day & $14^{\text {th }}$ Day & $21^{\text {st }}$ Day & $28^{\text {th }}$ Day \\
\hline \multicolumn{5}{|c|}{ Chromium (ppb) } \\
\hline Control & $98.69 \pm 4.85$ & $98.69 \pm 4.20$ & $98.69 \pm 3.30$ & $98.69 \pm 4.96$ \\
\hline $\mathrm{T}_{3}(60 \%)$ & $95.36 \pm 2.63$ & $90.96 \pm 2.51$ & $86.38 \pm 3.58$ & $82.16 \pm 4.65$ \\
\hline $\mathrm{T}_{4}(45 \%)$ & $92.56 \pm 2.77$ & $86.93 \pm 1.65$ & $81.16 \pm 1.23$ & $75.66 \pm 3.64$ \\
\hline $\mathrm{T}_{5}(30 \%)$ & $89.67 \pm 2.36$ & $80.57 \pm 1.16$ & $71.55 \pm 2.16$ & $62.44 \pm 2.84$ \\
\hline $\mathrm{T}_{6}(15 \%)$ & $85.35 \pm 3.19$ & $74.23 \pm 2.20$ & $66.02 \pm 3.65$ & $51.86 \pm 1.35$ \\
\hline \multicolumn{5}{|c|}{ Copper (ppb) } \\
\hline Control & $70.61 \pm 2.69$ & $70.61 \pm 2.21$ & $70.61 \pm 2.50$ & $70.61 \pm 1.06$ \\
\hline $\mathrm{T}_{3}(60 \%)$ & $67.66 \pm 3.97$ & $60.75 \pm 2.28$ & $51.54 \pm 3.64$ & $45.62 \pm 2.78$ \\
\hline $\mathrm{T}_{4}(45 \%)$ & $64.70 \pm 2.43$ & $52.23 \pm 2.05$ & $44.36 \pm 2.38$ & $38.27 \pm 3.86$ \\
\hline $\mathrm{T}_{5}(30 \%)$ & $61.71 \pm 3.03$ & $45.16 \pm 2.35$ & $37.12 \pm 3.08$ & $30.85 \pm 2.17$ \\
\hline $\mathrm{T}_{6}(15 \%)$ & $58.79 \pm 2.97$ & $35.18 \pm 1.35$ & $30.83 \pm 2.15$ & $20.68 \pm 0.99$ \\
\hline \multicolumn{5}{|c|}{ Iron (ppb) } \\
\hline Control & $66.32 \pm 1.76$ & $66.32 \pm 2.43$ & $66.32 \pm 2.49$ & $66.32 \pm 2.53$ \\
\hline $\mathrm{T}_{3}(60 \%)$ & $64.06 \pm 2.21$ & $60.13 \pm 3.22$ & $55.53 \pm 2.79$ & $50.59 \pm 1.44$ \\
\hline $\mathrm{T}_{4}(45 \%)$ & $61.96 \pm 2.36$ & $57.03 \pm 3.05$ & $51.33 \pm 3.11$ & $43.67 \pm 1.47$ \\
\hline $\mathrm{T}_{5}(30 \%)$ & $59.71 \pm 3.54$ & $55.58 \pm 3.09$ & $50.38 \pm 1.44$ & $41.56 \pm 1.52$ \\
\hline $\mathrm{T}_{6}(15 \%)$ & $57.25 \pm 3.10$ & $50.51 \pm 2.50$ & $44.27 \pm 2.31$ & $35.52 \pm 2.24$ \\
\hline \multicolumn{5}{|c|}{ Zinc (ppb) } \\
\hline Control & $36.34 \pm 2.60$ & $36.34 \pm 2.56$ & $36.34 \pm 3.03$ & $36.34 \pm 2.85$ \\
\hline $\mathrm{T}_{3}(60 \%)$ & $35.22 \pm 3.10$ & $34.10 \pm 2.28$ & $31.26 \pm 1.42$ & $28.66 \pm 1.77$ \\
\hline $\mathrm{T}_{4}(45 \%)$ & $33.10 \pm 2.07$ & $32.06 \pm 1.73$ & $27.35 \pm 2.04$ & $25.38 \pm 2.12$ \\
\hline $\mathrm{T}_{5}(30 \%)$ & $34.32 \pm 2.27$ & $33.32 \pm 1.29$ & $25.32 \pm 2.13$ & $21.26 \pm 1.40$ \\
\hline $\mathrm{T}_{6}(15 \%)$ & $32.78 \pm 2.13$ & $29.12 \pm 1.56$ & $23.79 \pm 2.45$ & $18.48 \pm 1.68$ \\
\hline \multicolumn{5}{|c|}{ Nickel (ppb) } \\
\hline Control & $12.86 \pm 1.38$ & $12.86 \pm 1.10$ & $12.86 \pm 0.62$ & $12.86 \pm 0.52$ \\
\hline $\mathrm{T}_{3}(60 \%)$ & $12.69 \pm 1.55$ & $12.54 \pm 0.95$ & $12.37 \pm 1.49$ & $12.18 \pm 1.04$ \\
\hline $\mathrm{T}_{4}(45 \%)$ & $12.50 \pm 1.08$ & $12.16 \pm 1.46$ & $11.80 \pm 1.30$ & $11.46 \pm 1.35$ \\
\hline $\mathrm{T}_{5}(30 \%)$ & $12.32 \pm 1.38$ & $11.51 \pm 1.34$ & $10.91 \pm 0.87$ & $10.76 \pm 1.12$ \\
\hline $\mathrm{T}_{6}(15 \%)$ & $12.17 \pm 1.04$ & $11.52 \pm 1.34$ & $10.82 \pm 1.13$ & $10.12 \pm 1.44$ \\
\hline
\end{tabular}

\section{Degradation of azo compounds by $C$. vulgaris}

GCMS analysis confirmed the degradation of azo compounds by $C$. vulgaris. Figure 4 a represents the GCMS analysis of raw tannery wastewater. Azo compounds such as 1H-1,2,4-triazole-3-yl-N-[2-(3methylphenoxy)ethyl] carboxamide (Mol-wt-246; RT30.99), 1,6-dihydroimidazo[4,5-d]imidazole (Mol-wt-108; RT-5.58) and 4-\{4-(3,5-dimethylphenyl)-2-[4(methylsulfonyl)phenyl]-1,3-thiazol-5-yl\}-2,6-

dimethylpyridine (Mol-wt-416; RT-31.45) were present in tannery wastewater. All the above compounds were absent in C. vulgaris treated wastewater (Figure 4b). The degradation of azo compounds by azo reductase in $C$. vulgaris was due to the breakage of $\mathrm{N}=\mathrm{N}$ bond (Lin and Liu, 1992).

\section{Conclusion}

Results of this investigation concluded that in tannery wastewater, C. vulgaris has a remarkable potential to survive as well as uptakes nutrients and heavy metals from tannery wastewater. Appreciable reduction of BOD and COD in tannery wastewater provides a space for the survival of other aquatic organisms. The mechanism of adsorption of heavy metals and uptake of nutrients from 

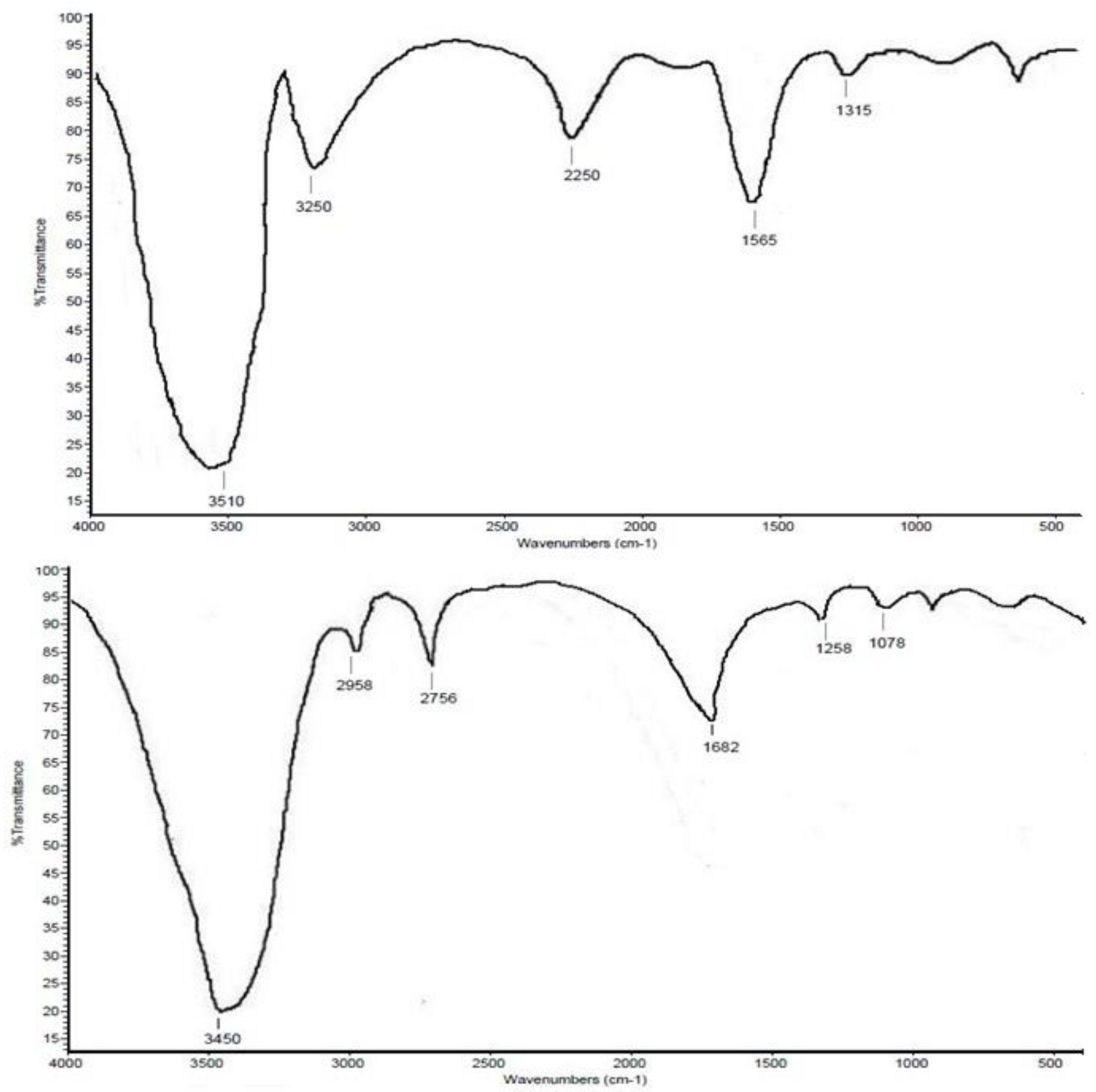

Figure 3. FT-IR spectra of raw and algal treated tannery wastewater.

wastewater will be studied in future.

\section{CONFLICT OF INTERESTS}

The authors have not declared any conflict of interests.

\section{ACKNOWLEDGMENT}

The research was supported by Bharathidasan University, Department of Environmental Science which provided the $C$. vulgaris. 
(a) Mass spectrum of 1,6-Dihydroimidazo[4,5-d] imidazole

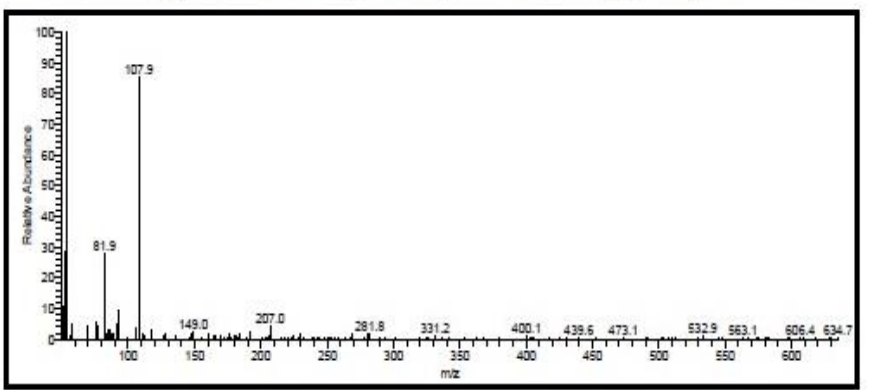

(C) Mass spectrum of 4-(4-(3,5-Dimethylphenyl)-2-[4-methyl sulfonyl)phenyl]-1,3-thiazol-5-yl\}2,6-dimethyl pyridine

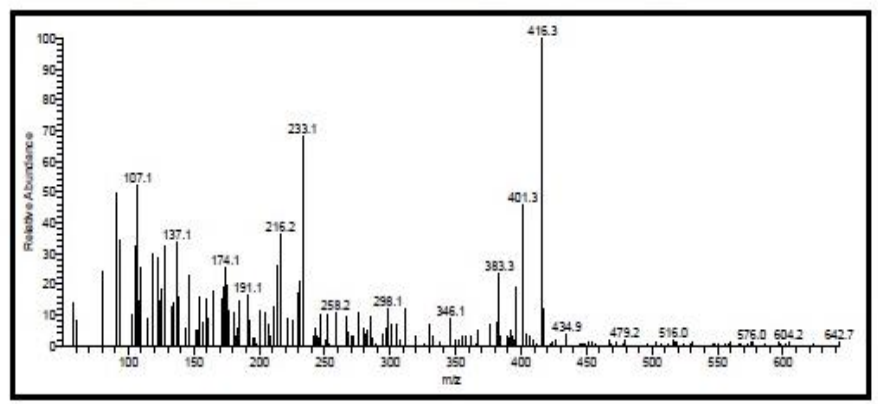

(I)

(a) Mass spectrum of 1,6-Methanofluorene

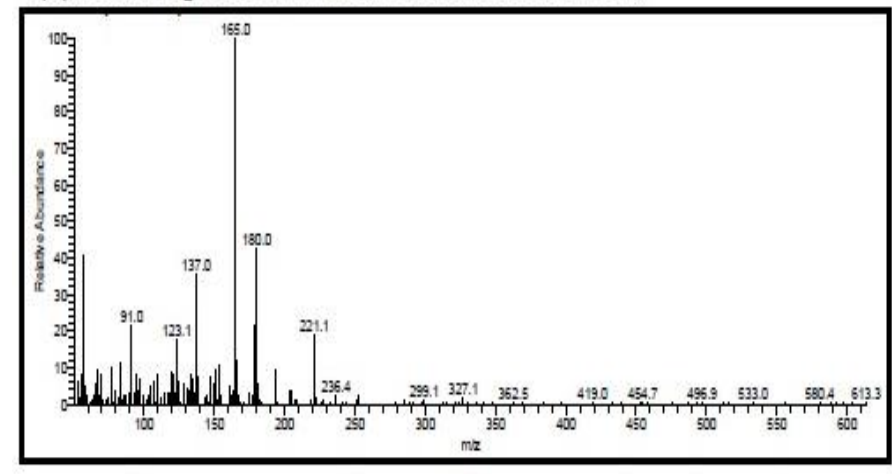

(c) Mass spectrum of 2,3,4,4a,5,6,- Hexahydroquinoline

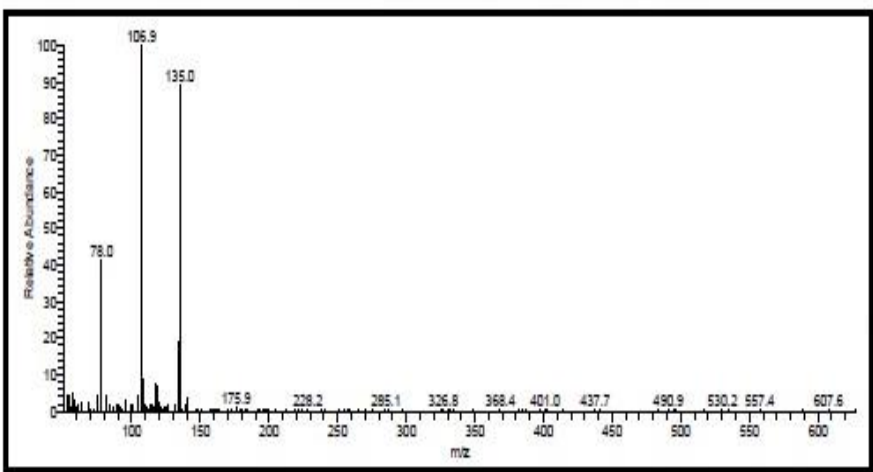

(II) (b) Mass spectrum of 1H-1,2,4-triazol-3-yl-N-[2-(3methylphenoxy)ethyl]carboxamide

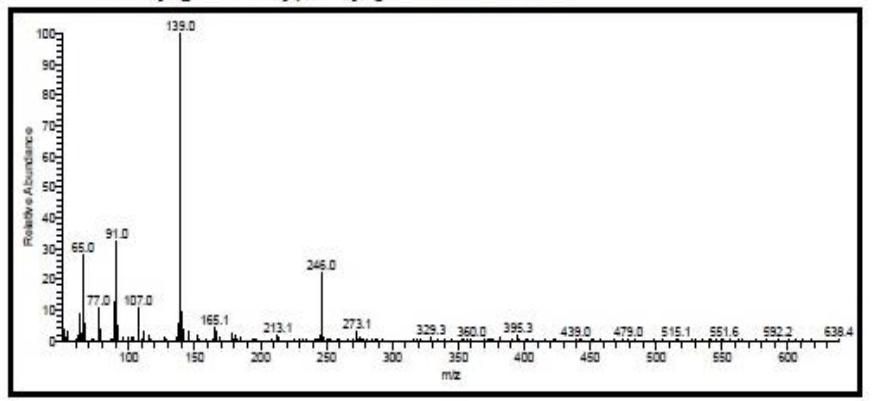

(b) Mass spectrum of,4-(2-propen-1-xyloxy) Benzeneamine

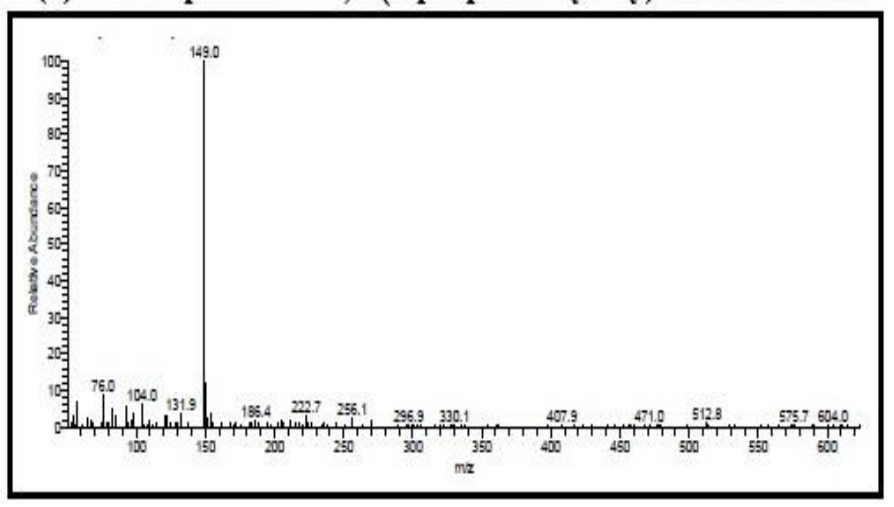

Figure 4. GC-MS analysis of i) raw and ii) treated tannery wastewater. 


\section{REFERENCES}

Ajayan KV, Selvaraju M (2011). Reflector based chlorophyll production by spirulina platensis through energy save mode. Bioresour. Technol. 102(16):7591-7594.

Ajayan KV, Selvaraju M (2012). Heavy metal induced antioxidant defense system of green microalgae and its effective role of phycoremediation of tannery effluent. Pak. J. Bio. Sci. 15:1056-1062.

Ajay KP, Vinay D (2012). Biodegradation of azo dye reactive red BL by Alcaligenes Sp. AA09. Int. J. Eng. Sci. 1(12):54-60.

Ajayan KV, Muthusamy S, Pachikaran U (2015). Phycoremediation of tannery wastewater using microalgae Scenedesmus species. Int. J. Phytorem. 17:907-916.

Arnon DI (1949). Copper enzymes in isolated chloroplasts, polyphenoxidase in beta vulgaris. Plant physiol. 24:1-15.

Ayodhaya DK (2013). Bioremediation of wastewater by using microalgae: an experimental study. Int. J. Life. Sci. Pharma. Rev. 2(3):340-346.

Balaji S, Kalaivani T, Sushma B (2016). Charaterization of sorption and differential stress response of microalgae isolates against tannery effluents from Ranipet industrial area - an application towards phycoremediation. Int. J. Phytorem. 18(8):747-753.

Balakumar K, Sharpudin J, Mubarak BH (2014). Comparative study of carbon sequestration by algae in domestic sewage and industrial effluent. Int. J. Emer. Technol. Adv. Eng. 4:807-809.

Becker EW (1994). Microalgae: Biotechnology and Microbiology. Cambridge Univesity Press, Cambridge, UK.

Bernhardt ES, Lawrence EB, Walsh CJ (2008). Understanding, managing and minimizing urban impacts on surface water nitrogen loading. Annals of the New York Academy Sciences, Year in Ecology and Conservation Biology, 61-96.

Borowitzka MA (1998). Limits to growth. In: Wong, Y.S., Tam, N.F.Y., (Eds.), Wastewater treatment with algae. Springer-Verlag, New York, pp. 203-226.

Chellam CT, Sampathkumar P (2012). Bio removal of nutrients in tannery effluent water using marine microalgae, Chlorella marina", Proceedings of International Forestery and Environment Symposium, Sri Lanka, Published by Department of Forestry and Environmental Science, University of Sri Jayewardenepura, P 17.

Chu WL, See YC, Phang SM (2009). Use of immobilised Chlorella vulgaris for the removal of colour from textile dyes. J. Appl. Phycol. 21:641-648

Cindrella D, Naseera K, Anirudh R (2016). Bioremediation of tannery wastewater by a salt-tolerant strain of Chlorella vulgaris. J. Appl. Phycol.. 29(1):235-243.

Clesceri LS, Greenberg AE, Trussel RR (1989). Standard Methods for the Examination of Water and Wastewater (17th Edition), American Public Health Association, Washington, DC

Deng L, Zhu X, Wang, X (2007). Biosorption of copper (II) from aqueous solutions by green alga Cladophora fascicularis. Biodegradation 18:393-402

Dilek D, Abel UU, Tulay O (2012). Fourier transform infrared (FTIR) spectroscopy for identification of Chlorella vulgaris Beijerinck 1890 and Scenedesmus obliqus (Turpin) Kutzing 1833. Afr. J. Biotechnol. 11(16):3817-3824.

Ding J, Zhao F, Cao Y (2015). Cultivation of microalgae in diary farm wastewater without sterilization. Int.J. Phytorem. 17(3):222-227.

Dinesh KS, Santhanam P, Jayalakshmi T (2015). Excessive nutrients and heavy metal removal from diverse wastewaters using marine microalgae Chlorella marina (Butcher). Ind. J. Geo-Marine Sci. 44(1).

Durai G, Rajasimman M (2011). Biological treatment of tannery wastewater - A review. J. Environ. Sci. Technol. 4:1-17.

Fraile A, Penche S, González F (2005). Biosorption of copper, zinc, cadmium and nickel by Chlorella vulgaris. Chem. Ecol. 21(1):61-75.

Gardea-Torresdey JL, Becker-Hapak MK, Hosea JMD (1990). Effect of chemical modification of algal carboxyl groups on metal ion binding. Environmen. Sci. Technol. 24(9):1372-1378.
Gupta VK, Rastogi A (2008). Equilibrium and kinetic modelling of cadmium (II) biosorption by nonliving algal biomass Oedogonium sp. from aqueous phase. J. Hazar. Mater. 153(1-2):759-766.

Hammouda O, Abdel-Raouf N, Shaaban M (2015). Treatment of mixed domestic-industrial wastewater using microalgae Chlorella sp. J. Am. Sci. 11(12):303-315.

Hanumantha RP, Ranjith KR, Raghavan BG (2011). Application of phycoremediation technology in the treatment of wastewater from a leather-processing chemical manufacturing facility. Water Sol. 37(1):7-14

Kishore J, Patil RT, Hitendra KL (2015). Bioprecipitation and biodegradation of fabric dyes by using Chara Sp. And Scenedesmus obliquus. J. Chem. Pharma. Res. 7(8):783-791.

Lauber CL, Hamady M, Knight R (2009). Pyrosequencing-based assessment of soil ph as a predictor of soil bacterial community composition at the continental scale. Appl. Environ. Microbiol. 75(15):5111-5120.

Lenore SC (1998). Standard Methods for the Examination of Water and Wastewater, (20th Edition), American Public Health Association, Washington, DC, USA.

Lin J, Liu H (1992). Degradation of azo dyes by algae. Environ. Pollu. 75(3):273-278.

Mehta SK, Tripathi BN, Gaur JP (2000). Influence of $\mathrm{pH}$, temperature, culture age and cations on adsorption and uptake of $\mathrm{Ni}$ by Chlorella vulgaris. Euro. J. Protist. 36(4):443-450.

Mehta SK, Gaur JP (2005). Use of algae for removing heavy metal ions from wastewater: progress and prospects. Crit. Rev. Biotechnol. 25(3):113-152.

Nandha S, Sarangi PK, Abraham J (2010). Cyanobacterial remediation of industrial effluents II. Paper mill effluents. New York Sci. J. 3(12):37-41.

Nichols HE (1973). Growth media freshwater. In: Stein, J., (Ed.), Handbook of Phycological Methods: Culture Methods and Growth Measurements. Cambridge University press, Cambridge, pp. 7-24.

Rai UN, Dwivedi S, Tripathi RD (2005). Algal biomass: an economical method for removal of chromium from tannery effluent. Bull. Environ. Contamin. Toxicol. 75(2):297-303.

Rehman A, Farah RS, Shakoori AR (2007). Heavy metal resistant Distigma proteus (Euglenophyta) isolated from industrial effluents and its possible role in bioremediation of contaminated wastewaters. Wor. J. Microbiol. Biotechnol. 23(6):753-758.

Rehman A (2011). Heavy metals uptake by Euglena proxima isolated from tannery effluents and its potential use in wastewater treatment. Russ. J. Ecol. 42(1):44-49.

Sharma GK, Khan SA (2013). Bioremediation of sewage wastewater using selective algae for manure production. Int. J. Environ. Eng. Manag. 4(6):573-580.

Sheehan J, Dunahay T, Benemann, J (1998). A look back at the US Department of energy's Aquatic sciences program-Biodiesel from algae. Golden, CO, National Renewable Energy institute, Report No. NREL/TP-580-24190.

Suresh KK. Hans UD, Eun JW (2015). Microalgae - A promising tool for heavy metal remediation. Ecotoxicol. Environ. Saf. 113:329-352.

Sivasubramanian V, Subramanian VV, Muthukumaran M (2012). Algal technology for effective reduction of total hardness in wastewater and industrial effluents. J. Phycol. Soc. (India). 42(1):51-58.

Yadavalli R, Rao CS, Rao RS (2014). Dairy effluent treatment and lipids production by Chlorella pyrenoidosa and Euglena gracilis: Study on open and closed systems. Asia-Pacific J. Chem. Eng. 9(3):368-373. 